conditioning by Ss in the contingent condition of the low basal group was only 8.0. Thus, the high basal rate of these Ss may have precluded the possibility of demonstrating conditioning, at least when using a reinforcer such as social approval.

The significant sex difference reported with respect to panel pushing during the basal period suggests that 1-year-old boys are more vigorous in such behavior than are girls of the same age. This is in line with other findings, suggesting that boys are more active and curious than are girls (Maccoby, 1966; Goldberg \& Lewis, 1969). The rise and fall in this behavior during the $6 \mathrm{~min}$ of testing suggests a strong exploratory interest in the movement of the panel, which was pursued by pounding the panel ever more rapidly at first, but which soon gave way to fatigue and loss of interest.

\section{REFERENCES}

G., \& LEWIS, M. Play behavior in the year-old infant: Early sex differences. Child Development, 1969. $40,21-31$.

HOROWITZ, F. D. Social reinforcement effects on child behavior. In $W$. W Hartup and N. L. Smothergill (Eds.), The young child: Reviews of research. Washington, D.C: National Association for the Education of Young Children 1967. Pp. 27-41

LIPSITT, L. P. Learning in the first year of life. In L. P. Lipsitt and C. C. Spiker (Eds.), Aduances in child development and behavior. Vol. 1. New York: Academic Press, 1963. Pp. 147-195.

M ACCOBY. E. E. (Ed.) The development of sex differences. Stanford: Stanford University Press, 1966

SCHAFFER, H. R., \& EMERSON, P. E. The development of social attachments in infancy. Monographs of the Society for Research in Child Development, 1964. 29(3, Whole No. 94).

\title{
Memory for intentions: The effect of presence of a cue and interpolated activity
}

\author{
ELIZABETH F. LOFTUS \\ New School for Social Research, New York, N.Y. 10011
}

Memory for intentions was investigated by asking $S$, at the beginning of the experiment, to remember to report, at the end of the experiment, the state in which he was born. Providing $S$ with a retrieval cue at the time he formed the intention facilitated S's recall of the intention. In addition, recall was more probable when fewer items intervened between the forming of the intention and the time at which it was supposed to be recalled. These results suggest that retention of intentions is not different from retention of other kinds of materials with respect to the influence of the two variables tested: presence of a cue and length of the retention interval.

A woman tells her husband that there is a party that night at 7:00 p.m. and asks that he be home early. He makes a "mental note" to leave his office at 5:00 p.m. to allow ample time. The husband intends to carry out a certain act. Intention may be defined as a determination to act in a certain way or to do a certain thing. 1

It has been suggested that forgetting an intention is not the same as forgetting a telephone number or forgetting a series of nonsense syllables learned during a psychological experiment (Miller, Galanter, \& Pribram, 1960, p. 68). Miller et al seem to agree with Freud (1952), who argues that forgetting of intentions has an "active" quality to it that is not involved in the kinds of forgetting Ebbinghaus studied. Specifically, Freud claims that when we forget to carry out an action which we have decided to do as a favor for others, we must feel antagonistic toward the duty; otherwise, we would not have forgotten (1952, p. 81).

It is possible that memory for all kinds of material has an "active" quality, in which case there is no reason, at this point, to single out memory for intentions as a special case. Rather, until solid evidence is presented to the contrary, it seems likely that the same mechanisms responsible for the forgetting of names, faces, nonsense syllables, and other material are also responsible for the forgetting of intentions.

One variable known to facilitate recall of words in a laboratory situation is the presence of a retrieval cue (e.g., Tulving \& Pearlstone, 1966). Since many kinds of cues are effective in getting a $S$ to recall desired items, it seems likely that retrieval cues would also be effective in getting a person to recall an intention. For example, does the husband think about going to the party all day, to the exclusion of other activities? If this be the case and if there are enough parties, he will lose his job. A "mental note" in the morning that he must get ready for the party at 5 p.m. would alleviate him of that burden. The clock in his office showing 5 p.m. would serve as a reminder and facilitate recall of his intention. Freud (1952, p. 79) said this much more elegantly: an "intention slumbers in the person concerned until the time for its execution approaches." It is expected that providing a person with a retrieval cue will "awaken" the intention and facilitate its recall.

A second variable known to affect traditional laboratory recall is the number of items intervening between learning and recall (e.g., Atkinson \& Shiffrin, 1968; Loftus \& Wickens, 1970 ). It seems likely that this variable would also affect memory for intentions. For example, if a wife asks her husband at 4:00 p.m. on Friday to be home early for a party that evening, it is more likely that he will remember to be home than if she asks him on the previous Tuesday. In the latter case, many more activities occur that potentially could interfere with his recall.

The present experiment examines the effect of these two variables, presence of a retrieval cue and number 
Table 1

Percentage of Ss Remembering to Report the State in Which They Were Born

\begin{tabular}{lcc} 
& 5 & 15 \\
& Questions & Questions \\
\hline Cue & .74 & .64 \\
No Cue & .62 & .44 \\
\hline
\end{tabular}

of intervening items, on the probability that an intention is recalled.

\section{METHOD}

The predictions stated above were tested in a field experiment in which Ss were asked to participate in an opinion survey. Before the survey began, all of the Ss were asked to report the state in which they were born at the end of the questionnaire. Half of the Ss were given a retrieval cue, half were not. Half of the Ss were asked five questions; the remainder were asked 15 questions. Thus, the experiment employed a 2 by 2 factorial design. The dependent measure was simply whether or not the $\mathrm{S}$ remembered to report his home state.

The Ss were 200 individuals connected with the New School for Social Research. The majority were New School students, some were staff members, and others were members of the New School community. The only criterion for choosing an individual to participate was that the individual be standing or sitting alone. Ss were assigned randomly to the four conditions, with the restriction that there be $50 \mathrm{Ss}$ in each condition.

The $E$ approached the $S$, introduced himself by name, and said that he was taking a survey for the Communications Department at New York University. In all conditions, he then proceeded: "I was wondering if you would mind answering a few questions about your opinions on some current issues. This information will be used for our public service publication, 'Public Opinion.' The survey will only take a few minutes, so I'd really appreciate your cooperation."

If the $\mathrm{S}$ agreed to participate and the $S$ was assigned to a no-cue condition, E then proceeded: "I will first ask you the questions and then, before I leave, I would appreciate it if you would tell me the state in which you were born. I can't get that information now because it might bias the survey."

If the $S$ agreed and the $S$ was assigned to a cue condition, $E$ then said: "The last question in the survey concerns the Black Panther Party, and after I ask you that question, I'd appreciate it if you'd tell me the state in which you were born. I can't get that information now because it might bias the survey."

The $S$ was then asked to answer either 5 or 15 questions. If the $S$ was assigned to a 15-question condition, he was asked the following questions:

(1) Are you a New School student?

(2) Your age?

(3) Are you married?

(4) Do you own a car?

(5) How long have you been in New York?

(6) How are you registered to vote-Republican, Democrat or other? (If you are not of voting age, how would you probably be registered?)

(7) Have you ever been out of the United States?

The $E$ then said: "In the following questions, I'll give you a statement and on a scale of 1 through 7, I'd like you to rate how much you agree or disagree with the statement. 'One' means 'strongly disagree' and 'seven' means 'strongly agree." "

(8) The Women's Liberation Movement is necessary for women to gain the rights which are justifiably theirs.

(9) R.O.T.C. has a place in a University community.

(10) Ted Kennedy does not deserve to become President of the United States after what he did at Chappaquiddick.

(11) The verdict handed down in the Chicago 7 trial left a black mark on the American judicial system.

(12) Capital punishment is not a valid crime deterrent and should therefore be abolished.

(13) John Lindsay has satisfactorily met up to his campaign promises.

(14) Richard Nixon should not be reelected President of the United States in 1972.

(15) The Black Panther Party has been unjustifiably smeered by the mass media.

If the $S$ was assigned to a 5-question condition, he was asked a random sample of two questions selected from Questions 1-7, a random sample of two questions selected from Questions 8-14, and then his last question was No. 15, the question on the Black Panther Party. After the last question had been asked, the $E$ thanked the $S$ and started to walk away. The $E$ recorded whether or not the $\mathrm{S}$ remembered to report his state.

RESULTS AND DISCUSSION

Apparently, the small request that the $S$ answer a few questions was not considered trivial by some of the Ss; seven people who were approached refused to answer any questions. Seven additional Ss were contacted, bringing the total to 200 . The analysis of results includes only the 200 Ss who agreed to participate.
The proportion of Ss in each condition who remembered to report the state in which they were born is presented in Table 1. Analysis of variance of the arc sine transformed proportions (Mosteller \& Tukey, 1949, p. 189) indicated that the presence of a cue-facilitated recall $\left(\mathrm{F}_{1, \infty}=5.45\right.$, $p<.05$ ) and that recall was more probable with 5 intervening questions than with 15 questions $\left(F_{1}=4.21\right.$, $p<.05)$. The interaction was not significant $\left(\mathrm{F}_{1, \infty}=.25, \mathrm{p}>.25\right)$.

These results suggest that the same mechanisms responsible for the forgetting of names, faces, nonsense syllables, words, and other material traditionally studied in the laboratory are also responsible for the forgetting of intentions. The two experimental variables studied here affect memory for intentions and memory for other material in similar ways. Just as the presence of a retrieval cue facilitated recall of words in experiments reported by Tulving \& Pearlstone (1966), so presence of a cue facilitated recall of an intention in the present experiment. Although relatively little is known about the conditions determining the exact nature and efficiency of retrieval cues, there can be no doubt that they are important in getting a $\mathrm{S}$ to recall desired items, whether they be words, nonsense syllables, or intentions. Similarly, just as the number of intervening items affected the probability of recalling the correct letter of the alphabet in an experiment reported by Loftus \& Wickens (1970), so the number of intervening questions affected recall of an intention in the present study.

\section{REFERENCES}

ATKINSON, R. C., \& SHIFFRIN, R. M Human memory: A proposed system and its control processes. In $K$. W. Spence and J. T. Spence (Eds.), The psychology of learning and motivation: Aduances in research and theory. Vol. 2. New York: Academic Press, 1968.

FREUD, S. Psychopathology of everyday life. New York: Mentor, 1952.

LOFTUS, G. R., \& WICKENS, T. D. Effect of incentive on storage and retrieval processes. Journal of Experimental Psychology, 1970, 85, 141-147.

MILLER, G. A., GALANTER, E., \& PRIBRAM, K. H. Plans and the structure of behavior. New York: Holt, Rinehart \& Winston, 1960.

MOSTELLER, F., \& TUKEY, J. W. The uses and usefulness of binomial probability paper. Journal of the American Statistical Association, 1949 44, 174-212.

TULVING, E., \& PEARLSTONE, $z$. Availability versus accessibility of information in memory for words. Journal of Verbal Learning \& Verbal Behavior, 1966, 5, 381-391. NOTE

1. Webster's New International Dictionary of the English Language, second edition (unabridged). G. \& C. Merriam, Springfield, Mass., 1957. 